\title{
Clinical and pathological features of Nerium oleander extract toxicosis in wistar rats
}

Tasleem Akhtar ${ }^{1}$, Nadeem Sheikh ${ }^{1 *}$ and Muddasir Hassan Abbasi ${ }^{1,2}$

\begin{abstract}
Background: Nerium oleander has been widely studied for medicinal purposes for variety of maladies. $N$. oleander has also been reported having noxious effects because of its number of components that may show signs of toxicity by inhibiting plasma lemma $\mathrm{Na}^{+}, \mathrm{K}^{+}$-ATPase. The present study was performed to scrutinize the toxic effect of $N$. oleander leaves extract and its clinical and pathological features in wistar rats.

Results: Hematological analysis showed significant variations in RBCs count ( $P=0.01), \mathrm{Hb}(P=0.001)$, Hct $(P=0.0003)$, MCV $(P=0.013)$, lymphocyte count $(P=0.015)$, neutrophil count $(P=0.003)$, monocyte count $(P=0.012)$ and eosinophil count $(P=0.006)$. Histopathological studies have shown that in $T_{1}$ group noticeable infiltration of inflammatory cells was found with low level of vascular damage. In $T_{2}$ group, increased proportion of binucleated and inflammatory cells, hepatic necrosis, widening of sinusoidal spaces and mild level of vascular damage was observed.

Conclusion: Taken together these findings we can conclude that $\mathrm{N}$. oleander leaves extract significantly affects on experimental animals due to its toxicity. Efforts must be exerted to purify different chemical components from extract with no inflammation as this plant is utilized in folk medicine with narrow therapeutic indices.
\end{abstract}

Keywords: Histopathology, Inflammation, Toxicity, Polycythemia, Macrocytosis, Neutrophilia

\section{Background}

Nerium oleander commonly known as "Kaner", belongs to the family Apocynaceae. It is native to Indo-Pak subcontinent, widely distributed in Mediterranean region, subtropical Asia, southern United States and many other warms areas [1] where it grows outdoors in parks, gardens and along roadsides by people who may not consider their toxic potential [2].

All parts of the plant are reputed as therapeutic agents and have been used in folklore in a variety of ailments including skin complaints, ringworm infections, opthalmia, cancer, epilepsy, eczema, malaria and gastrointestinal disturbances. Leaves and bark are also used as heart tonic, antibacterial, diuretic and anti-emetics [3-7].

On the contrary $N$. oleander has been regarded as poisonous plant due to a number of its components that may show signs of toxicity. Toxic exposure of humans and different species of domestic animals to $N$. oleander cardenolides occurs commonly throughout the geographic regions

\footnotetext{
* Correspondence: s_nadeem77@yahoo.com

${ }^{1}$ Cell and Molecular Biology Lab, Department of Zoology, University of the

Punjab, Q-A Campus, Lahore 54590, Pakistan

Full list of author information is available at the end of the article
}

where this plant grows [8]. The human mortality associated with ingestion of oleander is generally very low, but animals exposed to the plant are often found suddenly dead owing to cardiac dysfunction. $N$. oleander contains a mixture of very toxic cardiac glycosides of cardenolides, the most prominent of which are oleandrin and neriine $[9,10]$. Cardiac glycosides of $N$. oleander cause poisoning by inhibiting plasmalemmal $\mathrm{Na}^{+}, \mathrm{K}^{+}$-ATPase [11]. The plant has also been used for suicidal or murderous intention [12]. Accidental and/or experimental $N$. oleander toxicities have been reported in cattle [13], horses [14], sheep [8], goats [9], donkeys [15], camels [16], cats [17], dogs [18], monkeys [19], budgerigars [20], geese [21], ducks [22], turkeys [23], toed sloths [24] and bears [9].

The intention of this study was to determine the toxic nature of $N$. oleander leaves extract and its clinical and pathological features in Wistar rats.

\section{Methods}

\section{Animals}

Healthy Wistar rats (about $175 \pm 25$ g) were arranged from the department of Zoology, University of the Punjab Lahore, housed in wire-bottomed cages in an animal room 
under standard conditions with 12-h light/dark cycles and at an ambient temperature of $22 \pm 1^{\circ} \mathrm{C}$, with fresh water and food pellets available ad libitum in compliance with the institutional guidelines and the study was approved by the ethics committee of the department of Zoology, University of the Punjab Lahore.

\section{Dose preparation \& administration}

$N$. oleander leaves extract was prepared by boiling airdried leaves in $0.9 \% \mathrm{NaCl}$ solution $(1: 1, \mathrm{w} / \mathrm{v})$ for $3 \mathrm{~h}$ by steam distillation. The extract was then filtered and used to the experimental animals. Rats were alienated into three groups, designated as Con group for control animals and $\mathrm{T}_{1} \& \mathrm{~T}_{2}$ groups for experimental animals. $\mathrm{T}_{1} \& \mathrm{~T}_{2}$ groups were given with ad libitum access to $N$. oleander leaves extract for 3 and 7 days respectively, whereas Con group was given with normal drinking water.

\section{Blood \& liver tissue sampling and processing}

All the animals were anesthetized with intra-peritoneal injection of ketamine - distilled water mixture (1:1), (50 $\mathrm{mg} / \mathrm{ml}$ of ketamine) and scarified. The dissections were done in aseptic maintained conditions to draw the blood through direct cardiac puncture and excise the liver out. The blood samples were collected in sterilized disposable syringes (Becton Dickinson, Private Ltd.), $2 \mathrm{ml}$ of the blood was transferred to K3-EDTA coated vacutainers (Becton Dickinson, Private Ltd.) for complete blood count and liver of each animal, obtained after dissection was placed in Petri dish containing 0.9\% saline, cut into $1 \times 1 \mathrm{~cm}$ pieces and stored with $10 \%$ formalin in labeled glass bottles until.

\section{Evaluation of hematological parameters}

Complete blood counts were performed on the samples of control and treated animals, using an automated blood cell analyzer Sysmex XT-1800i (Japan). It utilizes the technology of fluorescent flow cytometry and hydrodynamic focusing. Fluorescent technology consistently differentiates normal white blood cells (WBCs), RBCs and platelets (plts) from abnormal populations, thereby decreasing the number of manual interventions.

\section{Evaluation of histopathological variations}

Small pieces of liver fixed in 10\% formalin were dehydrated in ethanol (40\%-100\%), cleared in xylene and embedded in paraffin wax. Sections (5 $\mu \mathrm{m}$ thick) were cut and stained with haematoxylin and eosin and examined for histopathological changes under the microscope (Olympus VANOX). The microphotographs were taken using digital camera (Nikon SLR-D3000) camera at original magnification of 100X \& 1000X.

\section{Statistical analysis}

The data were analyzed using Prism Graph pad 5 software (San Diego, CA). Statistical significance was calculated by means of one-way ANOVA test pursued by Tukey's post hoc analysis to assess differences against
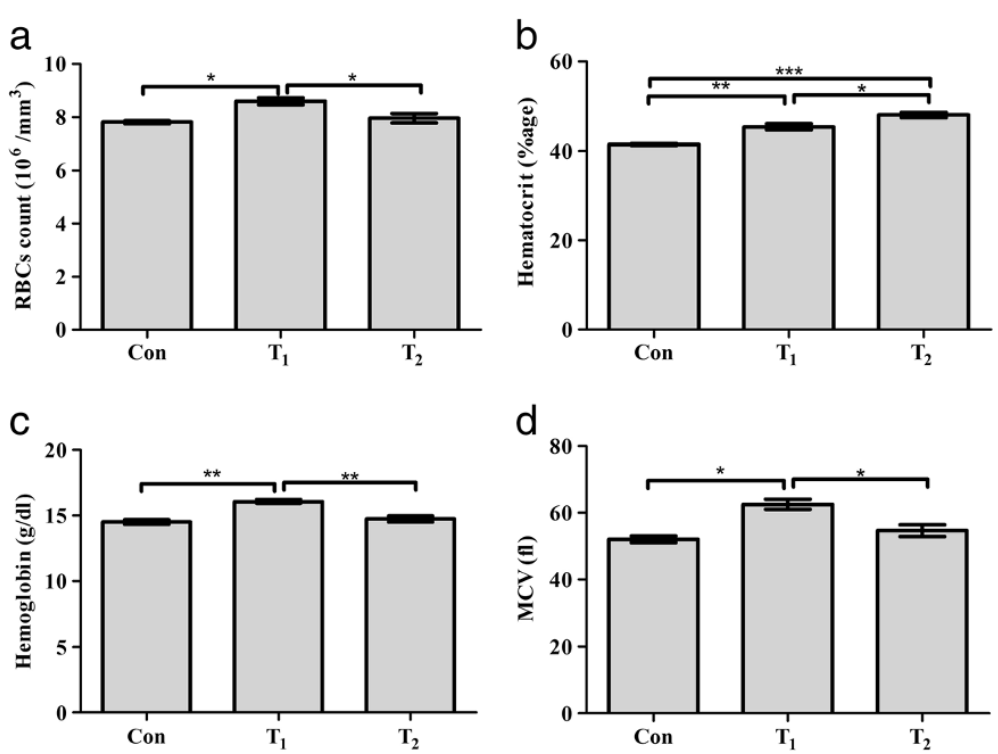

Figure 1 Hematological changes in the control and experimental groups. a: Effect of $N$. oleander leaves extract on RBCs count; $\mathbf{b}$ : Effect of $N$. oleander leaves extract on hematocrit level; $\mathbf{c}$ : Effect of $\mathrm{N}$. oleander leaves extract on hemoglobin level; $\mathbf{d}$ : Effect of $\mathrm{N}$. oleander leaves extract on MCV; Con (control group); $T_{1}$ (N. oleander oral intake for 3 days) and $T_{2}$ ( $N$. oleander oral intake for 7 days). Values are mean $\pm S E M$, error bar indicating the standard deviation. ${ }^{*}=\mathrm{P} \leq 0.05,{ }^{* *}=\mathrm{P} \leq 0.01,{ }^{* *}=\mathrm{P} \leq 0.001$. 
Table 1 Effect of $\boldsymbol{N}$. oleander leaves extract on Red blood cells count \& Red blood cell indices (Mean \pm SEM) Con, control; $T_{1}, N$. oleander oral intake for 3 days; $T_{2}, N$. oleander oral intake for 7 days

\begin{tabular}{lllll}
\hline & RBCs & Hct & Hb & MCV \\
\hline Con & $7.810 \pm 0.055$ & $41.430 \pm 0.185$ & $14.500 \pm 0.152$ & $52.000 \pm 1.000$ \\
$T_{1}$ & $8.600 \pm 0.125^{*}$ & $45.330 \pm 0.666^{* *}$ & $16.070 \pm 0.145^{* *}$ & $62.500 \pm 1.500^{*}$ \\
$T_{2}$ & $7.960 \pm 0.181$ & $48.000 \pm 0.577^{* * *}$ & $14.730 \pm 0.218$ & $54.670 \pm 1.764$ \\
\hline
\end{tabular}

Data were processed by one-way ANOVA followed by Tukey's post hoc: ${ }^{*} \mathrm{P}<0.05,{ }^{* *} \mathrm{P}<0.01$ and ${ }^{* * *} \mathrm{P}<0.001$

the control group and p-values less than or equal to 0.05 were thought-out significant.

\section{Results}

Consequence of $N$. oleander leaves extract on Red blood cells count \& Red blood cell indices

Blood level of Red blood cells (RBCs) reflects a statistical significant increment of $11 \%$ in $\mathrm{T}_{1}$ group with reference to con group while $\mathrm{T}_{2}$ group shows more or less a steady level of RBCs with minor increment $(\mathrm{P}=0.011)$ (Figure 1a). Hematocrit (Hct) contents show a statistical significant increase of $10 \%$ \& $16 \%$ respectively in $\mathrm{T}_{1} \& \mathrm{~T}_{2}$ groups as compared to con group $(\mathrm{P}=0.0003)$ (Figure $1 \mathrm{~b})$ while hemoglobin $(\mathrm{Hb})$ \& mean corpuscular volume $(\mathrm{MCV})$ reflect a significant increasing trend with $11 \%$ \& $20 \%$ increment in $\mathrm{T}_{1}$ group in comparison with con group. At the same the $\mathrm{T}_{2}$ group shows minor increase of $\mathrm{Hb} \& \mathrm{MCV}$, $2 \% \& 5 \%$ respectively as compared to con group $(\mathrm{P}=0.001$ $\& 0.013$ ) (Figure 1c,d and Table 1).

\section{Consequence of $N$. oleander leaves extract on differential leukocyte count}

A rise of $61 \%$ lymphocyte count in $\mathrm{T}_{1}$ group and $19 \%$ in $\mathrm{T}_{2}$ group with reference to the respective con group was observed $(\mathrm{P}=0.015)$ (Figure $2 \mathrm{a})$. Neutrophils exhibited a marked statistical increase of $357 \%$ in $\mathrm{T}_{2}$ group and a slight increase of $22 \%$ in $\mathrm{T}_{1}$ group concerning con group $(\mathrm{P}=0.003) \quad$ (Figure 2b). Monocytes and eosinophils showed an increase of $47 \%$ \& $290 \%$ respectively as compared to con group in $\mathrm{T}_{1}$ group, while a decline of $70 \%$ \& $40 \%$ respectively was noted in $\mathrm{T}_{2}$ group $(\mathrm{P}=0.012$ \& $\mathrm{P}=0.006$ respectively) (Figure $2 \mathrm{c}, \mathrm{d}$ and Table 2 ).

\section{Histopathological analysis}

In the Con group, the liver was free from any pathological abnormality, and H\&E stained sections appeared normal with regular cellular architecture. The hepatic cells had intact cytoplasm, sinusoidal spaces, prominent nucleus and nucleolus (Figure 3a). Analysis of $\mathrm{T}_{1}$ group revealed noticeable infiltration of inflammatory cells likely the lymphocytes around the hepatic arteries \& central vein with low level of vascular damage and individual cell necrosis (Figure $3 \mathrm{~b}$ ). In the $\mathrm{T}_{2}$ group, relatively increased proportion of binucleated cells in periportal area and inflammatory cells in perivascular area was found, indicating trigger of immune response of the organisms. Hepatic necrosis, widening of sinusoidal spaces and mild level of vascular damage was also observed in $\mathrm{H}$ \& $\mathrm{E}$ stained sections of liver tissue (Figure 3c).
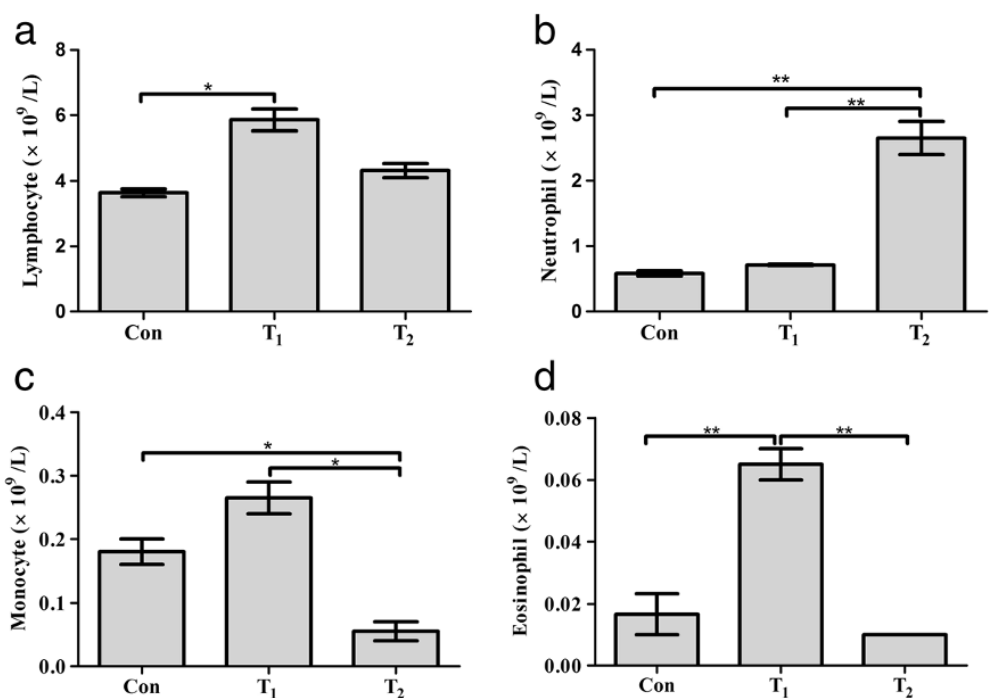

Figure 2 Differential leukocyte changes in the control and experimental group. a: Effect of $\mathrm{N}$. oleander leaves extract on lymphocyte count; b: Effect of $\mathrm{N}$. oleander leaves extract on neutrophil count; $\mathbf{c}$ : Effect of $\mathrm{N}$. oleander leaves extract on monocyte count; $\mathbf{d}$ : Effect of $\mathrm{N}$. oleander leaves extract on eosinophil count; Con (control group); $T_{1}$ ( $N$. oleander oral intake for 3 days) and $T_{2}$ ( $N$. oleander oral intake for 7 days). Values are mean \pm SEM, error bar indicating the standard deviation. ${ }^{*}=P \leq 0.05,{ }^{* *}=P \leq 0.01,{ }^{* * *}=P \leq 0.001$. 
Table 2 Effect of $\boldsymbol{N}$. oleander leaves extract on differential leukocyte count (mean \pm SEM) Con, control; $T_{1}$, $N$. oleander oral dose for $\mathbf{3}$ days; $\mathrm{T}_{2}$, N. oleander oral dose for $\mathbf{7}$ days

\begin{tabular}{lllll}
\hline & $\begin{array}{l}\text { Lymphocyte } \\
\text { count }\end{array}$ & $\begin{array}{l}\text { Neutrophil } \\
\text { count }\end{array}$ & $\begin{array}{l}\text { Monocyte } \\
\text { count }\end{array}$ & $\begin{array}{l}\text { Eosiniphil } \\
\text { count }\end{array}$ \\
\hline Con & $3.635 \pm 0.115$ & $0.580 \pm 0.040$ & $0.180 \pm 0.020$ & $0.016 \pm 0.006$ \\
$\mathrm{~T}_{1}$ & $5.860 \pm 0.330^{*}$ & $0.710 \pm 0.010$ & $0.265 \pm 0.025$ & $0.065 \pm 0.005^{* *}$ \\
$\mathrm{~T}_{2}$ & $4.315 \pm 0.215$ & $2.650 \pm 0.250^{* *}$ & $0.055 \pm 0.015^{*}$ & $0.010 \pm 0.000$ \\
\hline
\end{tabular}

Data were processed by one-way ANOVA followed by Tukey's post hoc: ${ }^{*} \mathrm{P}<0.05$ and ${ }^{*} \mathrm{P}<0.01$.

\section{Discussion}

$N$. oleander is considered as poisonous plant. It contains components such as oleandrin and neriine that cause damage by inhibiting pasmalemmal $\mathrm{Na}^{+}, \mathrm{K}^{+}$-ATPase [11]. In the present study the hematological and histopathological alterations were observed after $N$. oleander leaves extract administration in wistar rats. Hematological analysis indicates elevated level of RBCs, $\mathrm{Hb}$, Hct and MCV in experimental animals. Increased number of red blood cells is an indication of polycythemia. In polycythemia, the levels of $\mathrm{Hb}, \mathrm{Hct}$, \& RBCs are elevated when measured in the complete blood count $(\mathrm{CBC})$, as compared to normal [25]. Erythropoiesis occurs in the bone marrow. Erythropoietin (Epo) is one of the important hormones regulating this process [26]. The majority of Epo is produced and released by kidneys (90\%) and liver (10\%) [27,28]. Effect of extract on liver and kidney disturb the Epo expression directly or by disturbing other factors which are responsible for Epo expression. Under toxic conditions kidney release too much of protein (Epo) that enhance RBCs production. RBCs increase enhances the chance of clot formation, which can cause a heart attack or stroke. RBCs elevation is directly related to increase in Hb level [29]. Hct, Packed cell volume is the volumetric content of the RBCs in the blood [30]. Hct contents in the blood have been increased quit significantly (10\% \& 16\%) in experimental groups; Hct can be increased in various physiological conditions such as in Dengue Shock Syndrome, polycythemia, myeloproliferative disorders, COPD chronic obstructive pulmonary diseases and hypoxia [31,32]. The increase is in erythropoietin produced from the kidneys (specifically) is also the cause in increasing the Hct contents of the blood [33]. The erythropoietin is also been designated as a positive acute phase protein due to its extremely high up regulation in initial stages of Acute phase response [34]. The possible cause of increased Hct in the present study is increase in the MCV. The increase in MCV itself results in relative decrease in plasma [35]. 20\% increase in the MCV in $\mathrm{T}_{1}$ group blood analysis indicates a pathological state called as macrocytosis. The potent causes of the state are liver disease, compensated hemolysis, or folate deficiency [36].

Neutrophils and its derived cytokines play an essential part in the development and manifestation of inflammation. The stimulation of neutrophils can lead to the generation of oxygen derived free radicals also called reactive oxygen species (ROS) that cause further cellular damage. The formation of free radicals and cytotoxic oxygen metabolites probably impart a key role in various types of tissue degeneration and pathology such as aging, cancer and retinal degeneration [37,38]. In the present study, significant elevation in the neutrophil count (neutrophilia) occurs with 357\% rise in its level in $\mathrm{T}_{2}$ group as compared to control was may be due to the free radicals resulting from $N$. oleander leaves extract administration which caused liver injury and a proportion of these free radicals librated into the blood may also affect the circulating cells and induced a significant change in their number [39]. Elevated number of lymphocytes secretes different derivatives. IL-5, a derivative of lymphocytes is responsible for the stimulation and activation of eosinophils [40]. 47\% increase in
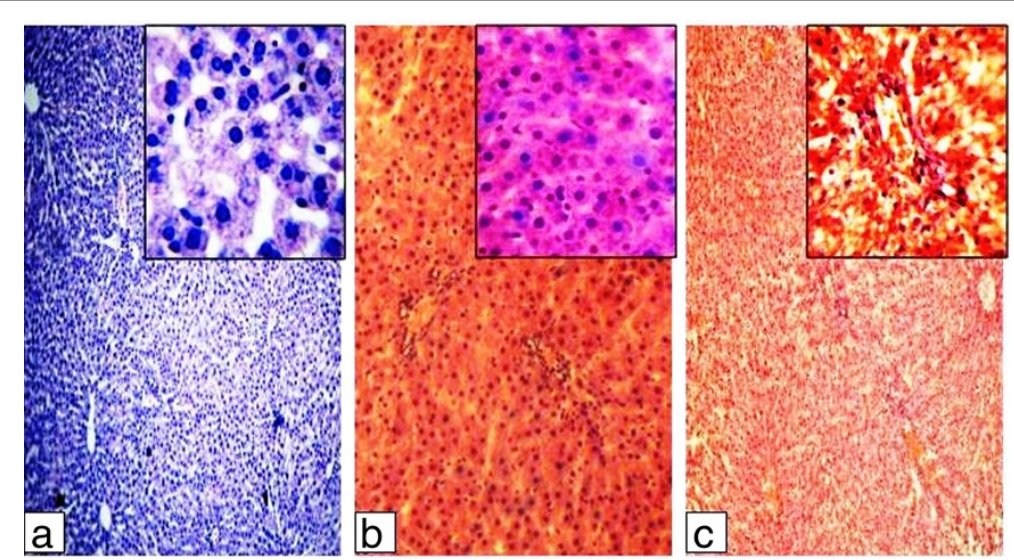

Figure 3 H \& E staining on liver tissue of (a) Control group, provided with normal drinking water, (b) $T_{1}$ group, provided with 3 days oral intake of $\boldsymbol{N}$. oleander extract and (c) $\mathrm{T}_{2}$ group, provided with 7 days oral intake of $\mathbf{N}$. oleander extract. Microphotographs were taken at $100 \mathrm{X} \& 1000 \mathrm{X}$ magnifications. 
monocytes count indicates a state of stress response, necrosis, red cell regeneration and sarcoidosis $[41,42]$.

Tissue inflammation performs a crucial job in liver pathology. Experimental groups show infiltration of immune cells, widening of sinusoidal spaces, elevated level of binucleated cells and individual cell necrosis. It has been well established that free radicals elicit an inflammatory response at the site of injury [43]. Toxic elements may induce pro-inflammatory cytokines by activating Kupffer cells [44]. TNF- $\alpha$, an important pro-inflammatory cytokine that is noticeably concerned in the progression or initiation of inflammatory response [45] and also stimulate the triggering of inflammatory mediators like IL-1, IL-6, TGF- $\beta$ and prostaglandins that facilitate cellular infiltration, vacuolation and necrosis in the liver $[46,47]$.

\section{Conclusions}

Taken together these findings we can conclude that $N$. oleander leaves extract significantly affects on hematological and histopathological parameters due to its toxicity. Efforts must be exerted to purify different chemical components from extract with no inflammation as this plant is utilized in folk medicine with narrow therapeutic indices. Seeing that, its use is risky and should be cautiously researched.

\section{Competing interests}

The authors declare that they have no competing interests.

\section{Authors' contributions}

TA carried out the experimental work, data analysis, interpretation of data and manuscript draft. NS provided the concept, participated in the design of study, supervised the manuscript draft and approved the final manuscript. MHA participated in its design, data analysis and coordination. All authors read and approved the final manuscript.

\section{Acknowledgements}

The authors are thankful to the Vice Chancellor, University of the Punjab Lahore, Pakistan for providing financial support for the publication of this manuscript.

\section{Author details}

${ }^{1}$ Cell and Molecular Biology Lab, Department of Zoology, University of the Punjab, Q-A Campus, Lahore 54590, Pakistan. ${ }^{2}$ Department of Zoology, Government College of Science, Wahdat Road, Lahore 54590, Pakistan.

Received: 28 April 2014 Accepted: 12 December 2014

Published: 23 December 2014

\section{References}

1. Rashan L, Franke K, Khine MM, Kelter G, Fiebig HH, Neumann J, Wessjohann LA: Characterization of the anticancer properties of monoglycosidic cardenolides isolated from Nerium oleander and Streptocaulon tomentosum. J Ethnopharmacol 2011, 134:781-788.

2. O'Leary SB: Poinoning in man from eating poisonous plants. Arch Environ Hith 1964, 9:216-242.

3. Bai L, Zhao M, Toki A, Sakai J, Yang XY, Bai Y, Ando M, Hirose $K$, Ando M: Three new cardenolides from methanol extract of stems and twigs of Nerium oleander. Chem Pharm Bull (Tokyo) 2010, 58:1088-1092.

4. Haq MM, Jabbar A, Rashid MA, Hasan M: A novel antibacterial and cardiac steroid from the roots of Nerium oleander. Fitoterapia 1999, 70:5-9.

5. Singhal KG, Gupta GD: Some Central Nervous System Activities of Nerium Oleander Linn (Kaner) Flower Extract. Trop J Pharm Res 2011, 10:455-461.
6. Suganya RS, Priya K, Roxy BM: Phytochemical screening and antibacterial activity from Nerium oleander and evaluate their plant mediated nanoparticle synthesis. Int Res J Pharm 2012, 3:285-288.

7. Sugimoto H, Kataoka T, Igarashi M, Hamada M, Takeuchi T, Nagai K: E-73, an acetoxyl analogue of cycloheximide, blocks the tumor necrosis factorinduced NF-kappaB signaling pathway. Biochem Biophys Res Commun 2000, 277:330-333

8. Aslani MR: Poisonous plants of Iran and their effects on animals. 1st edition. Mashhad: Mashad university press; 2004:210-212.

9. Aslani MR, Movassaghi AR, Janati-Pirouz H, Karazma M: Experimental oleander (Nerium oleander) poisoning in goats: a clinical and pathological study. Iran J Vet Res 2007, 8:58-63.

10. Langford SD, Boor PJ: Oleander toxicity: an examination of human and animal toxic exposures. Toxicology 1996, 109:1-13.

11. Barbosa RR, Fontenele-Neto JD, Soto-Blanco B: Toxicity in goats caused by oleander (Nerium oleander). Res Vet Sci 2008, 85:279-281.

12. Lim DC, Hegewald K, Dandamudi N, Pettis L: A suicide attempt with an oleander cocktail. Chest 1999, 116:405-406.

13. Aslani MR, Rezakhani A: A case report of oleander (Nerium oleander) intoxication in cattle. Int J Trop Agric 2000, 18:185-187.

14. Hughes KJ, Dart AJ, Hodgson DR: Suspected Nerium oleander (Oleander) poisoning in a horse. Aust Vet J 2002, 80:412-415.

15. Smith PA, Aldridge BM, Kittleson MD: Oleander toxicosis in a donkey. J Vet Intern Med 2003, 17:111-114

16. Vashishta MS, Singh RP: Camel diseases in India. 1st edition. Calcutta: Scientific Book Agency; 1977:75-76.

17. Burton LE, Picchioni $A L$, Chin L: Dipotassium edetate as an antidote in poisoning from oleander and its chief glycoside, oleandrin. Arch Int Pharmacodyn Ther 1965, 158:202-211.

18. Humphreys DJ: Veterinary Toxicology. 1st edition. London: Bailliere Tindall; 1988.

19. Schwartz WL, Bay WW, Dollahite JW, Storts RW, Russell LH: Toxicity of Nerium oleander in the monkey (Cebus apella). Vet Pathol 1974, 11:259-277.

20. Shropshire CM, Stauber E, Arai M: Evaluation of selected plants for acute toxicosis in budgerigars. J Am Vet Med Assoc 1992, 200:936-939.

21. Alfonso HA, Sanchez LM, Merino N, Gomez BC: Intoxication due to Nerium oleander in geese. Vet Hum Toxicol 1994, 36:47.

22. Bardosi Z: Intoxication caused by oleander leaves. Magy Allatorv Lap 1963, 18:361.

23. Shlosberg A, Ohad DG, Bellaiche M, Perl S: Monitoring of physiological and pathological changes in turkey poults fed leaves of potentially cardiomyotoxic Nerium oleander and Persea ameicana., 1st edn. Massachusetts: CABI Publishers; 2004.

24. Miller R: Oleander poisoning in a two toed sloth. J Zoo Anim Med 1973 $4: 14$.

25. Jepson JH: Polycythemia: diagnosis, pathophysiology and therapy. II. Can Med Assoc J 1969, 100:327-334.

26. Aapro M, Jelkmann W, Constantinescu SN, Leyland-Jones B: Effects of erythropoietin receptors and erythropoiesis-stimulating agents on disease progression in cancer. Br J Cancer 2012, 106:1249-1258.

27. Eckardt KU, Ratcliffe PJ, Tan CC, Bauer C, Kurtz A: Age-dependent expression of the erythropoietin gene in rat liver and kidneys. J Clin Invest 1992, 89:753-760.

28. Koury MJ, Bondurant MC: The mechanism of erythropoietin action. Am J Kidney Dis 1991, 18:20-23.

29. TOGNELLA S, BIGNOTTI G: Cardiovascular syndromes in polycythemia vera. Recenti Prog Med 1964, 36:43-82.

30. Theml H, Heinz D, Haferlach T: Color Atlas of Hematology; Practical Microscopic and Clinical Diagnosis, 2nd revised edn. New York: Thieme New York; 2004.

31. Gross NJ: Chronic obstructive pulmonary disease. Current concepts and therapeutic approaches. Chest 1990, 97:19S-23S.

32. Kociba GJ: Erythrocytes. Vet Clin North Am Small Anim Pract 1989, 19:627-635.

33. Ramadori P, Ahmad G, Ramadori G: Cellular and molecular mechanisms regulating the hepatic erythropoietin expression during acute-phase response: a role for IL-6. Lab Invest 2010, 90:1306-1324.

34. Ramadori P, Sheikh N, Ahmad G, Dudas J, Ramadori G: Hepatic changes of erythropoietin gene expression in a rat model of acute-phase response. Liver Int 2010, 30:55-64.

35. Greer JP, John F, Lukens JN: Wintrobe's Clinical Hematology, 11th edn Philadelphia: Williams \& Wilkins Publishers; 2003. 
36. Munker R: Modern Hematology; Biologyand Clinical Management. 2nd edition. Totowa, New Jersey: Human Press Inc.; 2007.

37. Hussain SP, Harris CC: Inflammation and cancer: an ancient link with novel potentials. Int J Cancer 2007, 121:2373-2380.

38. Reznick AZ, Shehadeh N, Shafir Y, Nagler RM: Free radicals related effects and antioxidants in saliva and serum of adolescents with Type 1 diabetes mellitus. Arch Oral Biol 2006, 51:640-648.

39. Doi K, Kurabe S, Shimazu N, Inagaki M: Systemic histopathology of rats with CCl4-induced hepatic cirrhosis. Lab Anim 1991, 25:21-25.

40. Hamid Q, Azzawi M, Ying S, Mogbel R, Wardlaw AJ, Corrigan CJ, Bradley B, Durham SR, Collins JV and Jeffery PK: Expression of mRNA for interleukin-5 in mucosal bronchial biopsies from asthma. J Clin Invest 1991, 87:1541-1546.

41. Fingerle G, Pforte A, Passlick B, Blumenstein M, Strobel M, Ziegler-Heitbrock HW: The novel subset of CD14+/CD16+ blood monocytes is expanded in sepsis patients. Blood 1993, 82:3170-3176

42. Fingerle G, Angstwurm M, Andreesen R, Ziegler-Heitbrock HW: Selective depletion of CD14+ CD16+ monocytes by glucocorticoid therapy. Clin Exp Immunol 1998, 112:501-506.

43. Padhy BM, Srivastava A, Kumar VL: Calotropis procera latex affords protection against carbon tetrachloride induced hepatotoxicity in rats. J Ethnopharmacol 2007, 113:498-502.

44. Shito M, Balis UJ, Tompkins RG, Yarmush ML, Toner M: A fulminant hepatic failure model in the rat: involvement of interleukin-1 beta and tumor necrosis factor-alpha. Dig Dis Sci 2001, 46:1700-1708.

45. Hishinuma I, Nagakawa J, Hirota K, Miyamoto K, Tsukidate K, Yamanaka T, Katayama K, Yamatsu I: Involvement of tumor necrosis factor-alpha in development of hepatic injury in galactosamine-sensitized mice. Hepatology 1990, 12:1187-1191.

46. Basu A, Sen T, Ray RN, Chaudhuri AK: Hepatoprotective effects of Calotropis procera root extract on experimental liver damage in animals. Fitoterapia 1992, 63:507-514.

47. Wang H, Wei W, Wang NP, Gui SY, Wu L, Sun WY, Xu SY: Melatonin ameliorates carbon tetrachloride-induced hepatic fibrogenesis in rats via inhibition of oxidative stress. Life Sci 2005, 77:1902-1915.

doi:10.1186/1756-0500-7-947

Cite this article as: Akhtar et al: Clinical and pathological features of Nerium oleander extract toxicosis in wistar rats. BMC Research Notes 2014 7:947.

\section{Submit your next manuscript to BioMed Central and take full advantage of:}

- Convenient online submission

- Thorough peer review

- No space constraints or color figure charges

- Immediate publication on acceptance

- Inclusion in PubMed, CAS, Scopus and Google Scholar

- Research which is freely available for redistribution 